\title{
TWENTY-THREE CASES OF PNEUMONIA TREATED WITH ANTIPNEUMOCOCCUS SERUM *
}

\author{
WILLIAM R. WILLTAMS, M.D. \\ Attending Physician New York Hospital \\ NEW YOBK
}

Through the cooperation of the Research Laboratory I was able to give a series of patients suffering from lobar pneumonia an antipneumococcus serum, and although the results were somewhat inconclusive, it seems desirable to publish them.

The series includes practically all of the pneumonia patients admitted to the service of the Second Medical Division of New York Hospital during the period of the test. This division receives all medical patients admitted to the hospital on the even days of the month, while those admitted on the odd days go to the first division. Although this method of assignment does not give a strict alternation of patients, yet it seemed justifiable to use the patients on the first division as controls, inasmuch as none of them received any serum.

'The serum was taken from a horse immunized against many strains of pneumococci. ${ }^{1}$ Usually it was injected directly into a vein of the arm at a temperature about that of the patient. This rule was departed from and the serum was given subcutaneously to two children on account of the difficulty of entering the vein with the needle, and also when second and later doses were given to four adult patients who had received the initial dose intravenously. The first doses for adults in the earlier cases was 100 c.c. This was increased later until, in one instance, an initial dose of 300 c.c. was given. Many of the patients received more than one dose so that the total amount of serum that an individual received ranged from 50 to 750 c.c. This maximal quantity was given in six doses spread over a period of five days.

A complete demonstration of the nature of the infecting organism was not essayed. Blood-cultures, however, were made in eleven cases. Only one of them (Case 11) showed the pneumococcus, the others being negative. In Case 6, pneumococci were cultivated from pus from the pleural cavity. Cultures were made from the sputum in several instances. ${ }^{1}$ The diagnosis was based on the clinical evidences of pneumonia, special weight being given to the presence of rusty sputum and

* Submitted for publication Jan. 28, 1914.

* From the New York Hospital and Research Laboratory, Department of Health, City of New York.

1. See Notes on Serum, CuItures, Etc., following. 
the physical signs of a definite consolidation of the lung. In every case the subsequent course of the illness confirmed the diagnosis of lobar pneumonia and strengthened the probability of the existence of a pneumococcus infection.

The chief points of note in these cases are given in a very condensed form in Table 1, together with the details of the dosage of the serum. The time of onset of pneumonia is not uncommonly indefinite. Many patients give a history of an indefinite illness lasting for several days, during which time they may not have been confined to bed continuously. This may explain the duration of some of the more protracted cases of this series. Most of the patients, however, gave symptoms that fixed the beginning of the pneumonia with a reasonable degree of accuracy.

A review of the data of Table 1 shows that the series included twentythree cases with sixteen recoveries and seven deaths, a mortality of 30.5 per cent. Of the seven patients who died, three were alcoholics, one of whom had suffered from two previous attacks of pneumonia, and all were very actively delirious. A fourth death was that of a baby (Case 4), who, in addition to pneumonia, had multiple abscesses of the scalp, double purulent otitis media, and empyema followed by pneumothorax. The remaining three deaths seemed to have been due to the frank intensity of the pneumonia.

Of the sixteen patients who recovered, eight had defervescence by crisis and eight by lysis. The crisis occurred on the following days: fourth, fifth to sixth, sixth, seventh, ninth, eleventh, twelfth, and on the eighteenth to nineteenth. The onset of the lysis in the other cases in which the patients recovered occurred on the following days: sixth, seventh (three cases), eighth, tenth and on the thirteenth day. In the remaining cases the onset of the lysis was scarcely definable because the fall of temperature was so gradual. Five patients had complications. In one instance this was serous pleurisy (Case 5). In cases 6 and 19 empyema developed. In Case 4 the signs and symptoms were those of empyema, but an exploratory puncture failed to find the pus. On the next day, however, there was evidence of pneumothorax, and on operation considerable pus was found. Two days later the child died with edema of the lungs. She was extremely ill from the time of admission and had in addition to the pleural complications, double otitis media for which the drum membranes were incised, and also many abscesses of the scalp. Otitis was detected in Case 18 also. The series offered an opportunity to observe the effects of the administration of large and frequent doses of horse-serum that had not been refined in any manner and that contained no preservative except a trace of chloroform. ${ }^{1}$ Usually no immediate effects could be detected and the injection of the serum was 


\begin{tabular}{|c|c|c|c|c|c|c|}
\hline \multirow{2}{*}{$\begin{array}{l}\text { Case } \\
\text { No. }\end{array}$} & \multirow{2}{*}{$\begin{array}{l}\text { Sex, }{ }^{*} \text { Age in } \\
\text { Years, Habits, } \\
\text { Etc. }\end{array}$} & \multicolumn{4}{|c|}{ Condition of Patient } & \multirow{2}{*}{$\begin{array}{c}\text { Blood- } \\
\text { Culture, Etc. }\end{array}$} \\
\hline & & $\begin{array}{l}\text { Day of } \\
\text { Admission }\end{array}$ & Invasion & $\begin{array}{c}\text { Temperature } \\
\text { Pulse } \\
\text { Respiration }\end{array}$ & $\begin{array}{l}\text { Site } \\
\text { Lesion }\end{array}$ & \\
\hline 1 & $\$ 12$ & 3 & Chill & $\begin{array}{l}\text { T. } 104^{\circ}-5^{\circ} \\
\text { P. } 132 \\
\text { R. } 28\end{array}$ & L. L. & Sterile \\
\hline 2 & \& $11 / 4$ & $15(?)$ & Chill & $\begin{array}{ll}\text { T. } & 104.8^{\circ} \\
\text { P. } & 160 \\
\text { R. } & 50\end{array}$ & $\begin{array}{l}\text { R. U. } \\
\text { L. U. }\end{array}$ & $\ldots \ldots \ldots \ldots$ \\
\hline 3 & $\begin{array}{l}\hat{A} \quad 4 \mathrm{I} \\
\text { Alcoholic }\end{array}$ & 8 & Chill & $\begin{array}{lr}\text { T. } & 103^{\circ} \\
\text { P. } & 124 \\
\text { R. } & 48\end{array}$ & $\begin{array}{l}\text { R. M. } \\
\text { R. L. }\end{array}$ & $\cdots \cdots \cdots \cdots$ \\
\hline 4 & 5 & 6 & $\ldots \ldots \ldots \ldots$ & $\begin{array}{l}\text { T. } 106^{\circ} \\
\text { P. } 140 \\
\text { R. } 48\end{array}$ & R. U. & $\ldots \ldots \ldots \ldots$ \\
\hline 5 & A 26 & 2 & Chill & $\begin{array}{lr}\text { T. } & 106^{\circ} \\
\text { P. } & 116 \\
\text { R. } & 28\end{array}$ & L. L. & Sterile \\
\hline 6 & ᄎ 17 & 4 & Chill & $\begin{array}{lc}\text { T. } & 105^{\circ} \\
\text { P. } & 128 \\
\text { R. } & 40\end{array}$ & R. L. & Sterile \\
\hline 7 & 830 & 5 & Chilly & $\begin{array}{l}\text { T. } 103.6^{\circ} \\
\text { P. } 108\end{array}$ & $\begin{array}{l}\text { R. U. } \\
\text { R. M. }\end{array}$ & $\cdots \cdots$ \\
\hline 8 & o 30 & 2 & Chill & $\begin{array}{l}\text { R. } \quad 32 \\
\text { T. } 105^{\circ} \\
\text { P. } 112 \\
\text { R. } \quad 24\end{array}$ & R. U. & Sterile \\
\hline 9 & \& 29 & 2 & Cough, pain & $\begin{array}{ll}\text { T. } & 103^{\circ} \\
\text { P. } & 1: 10\end{array}$ & R. L. & Sterile \\
\hline 10 & ๙ิ 46 & 7 & Chill & $\begin{array}{ll}\text { R. } & 40 \\
\text { T. } & 104.6^{\circ} \\
\text { P. } & 108 \\
\text { R. } & 32\end{array}$ & I. J. & Sterile \\
\hline
\end{tabular}

* In this column $\hat{\sigma}$ denotes male and $q$ female. 


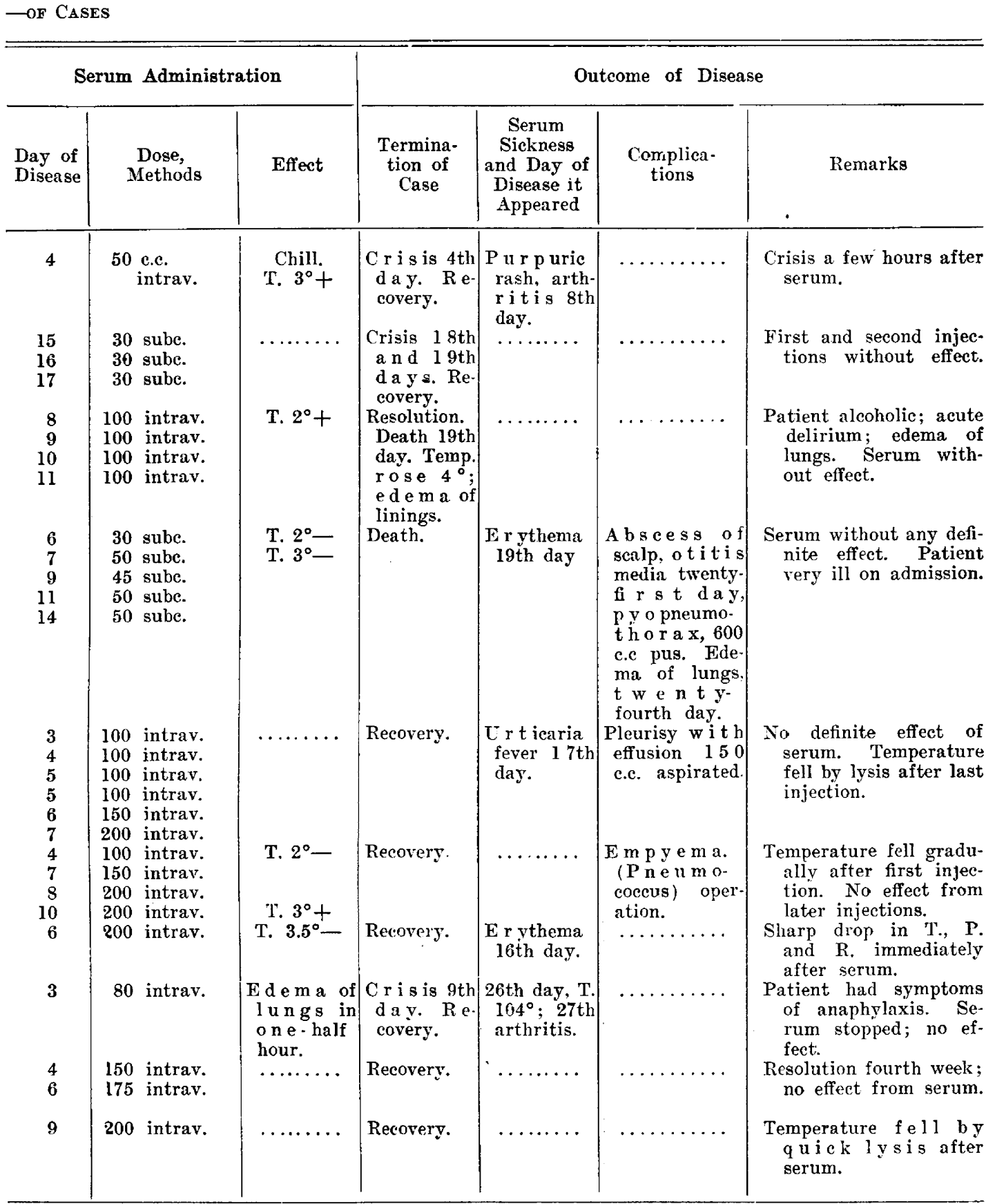


Table 1.-

\begin{tabular}{|c|c|c|c|c|c|c|}
\hline \multirow{2}{*}{$\begin{array}{l}\text { Case } \\
\text { No. }\end{array}$} & \multirow{2}{*}{$\begin{array}{l}\text { Sex, * Age in } \\
\text { Years, Habits, } \\
\text { Etc. }\end{array}$} & \multicolumn{4}{|c|}{ Condition of Patient } & \multirow{2}{*}{$\begin{array}{c}\text { Blood- } \\
\text { Culture, Etc. }\end{array}$} \\
\hline & & $\begin{array}{l}\text { Day of } \\
\text { Admission }\end{array}$ & Invasion & $\begin{array}{c}\text { Temperature } \\
\text { Pulse } \\
\text { Respiration }\end{array}$ & $\begin{array}{c}\text { Site } \\
\text { Lesion }\end{array}$ & \\
\hline $1 I$ & $\begin{array}{l}\text { Â } 39 \\
\text { Alcoholic }\end{array}$ & 6 & $\cdots \cdots \cdots \cdots$ & $\begin{array}{l}\text { T. } 104^{\circ} \\
\text { P. } 100 \\
\text { R. } \quad 36\end{array}$ & $\begin{array}{l}\text { I. U. U. } \\
\text { L. L. }\end{array}$ & $\begin{array}{l}\text { Pneumo- } \\
\text { coccus }\end{array}$ \\
\hline 12 & $\begin{array}{ll}\hat{f} & 16 \\
\text { In extremis }\end{array}$ & 2 & $\ldots \ldots \ldots \ldots$ & T. $107^{\circ}$ & R. L. & $\ldots \ldots \ldots$ \\
\hline 13 & 우 2 & 5 & $\cdots \ldots \ldots$ & $\begin{array}{l}\text { I. } 105^{\circ} \\
\text { P. } 136 \\
\text { R. } 40\end{array}$ & L. L. & $\ldots \ldots \ldots$ \\
\hline 14 & $\begin{array}{l}\text { of } 38 \\
\text { Alcoholie; } \\
\quad \text { third attack }\end{array}$ & 6 & $\ldots \ldots \ldots \ldots$ & $\begin{array}{l}\text { T. } 103.6^{\circ} \\
\text { P. } 124 \\
\text { R. } 24\end{array}$ & R. U. & $\cdots \cdots \cdots$ \\
\hline 15 & ô 24 & $8(?)$ & $\ldots \ldots \ldots$ & $\begin{array}{l}\text { T. } 105.4^{\circ} \\
\text { P. } 102 \\
\text { R. } \quad 32\end{array}$ & R. L. & $\begin{array}{c}\text { Sterile } \\
\text { Plasmodium } \\
\text { malariae }\end{array}$ \\
\hline 16 & क 24 & 3 & Chill & $\begin{array}{lr}\text { T. } & 105^{\circ} \\
\text { P. } & 144 \\
\text { R. } \quad 40\end{array}$ & L. L. & Sterile \\
\hline 17 & ô $41 / 2$ & 11 & Chill, cough & $\begin{array}{l}\text { T. } 101^{\circ} \\
\text { P. } 118\end{array}$ & L. I. & $\cdots \ldots \ldots \ldots$ \\
\hline 18 & $\begin{array}{l}\text { Â. } 30 \\
\text { Alcoholic }\end{array}$ & 6 & $\ldots \ldots \ldots \ldots$ & $\begin{array}{lr}\text { R. } & 32 \\
\text { T. } & 105^{\circ} \\
\text { P. } & 128 \\
\text { R. } & 44\end{array}$ & L. U. & $\ldots \ldots \ldots \ldots$ \\
\hline 19 & ô 32 & 4 & Chill & $\begin{array}{l}\text { T. } 104.6^{\circ} \\
\text { P. } 120 \\
\text { R. } 44\end{array}$ & L. L. & $\ldots \ldots \ldots \ldots$ \\
\hline 20 & ô 13 & 3 & Chill & $\begin{array}{l}\text { T. } 102^{\circ} \\
\text { P. } 120\end{array}$ & R. L. & Sterile \\
\hline 21 & ¿ 54 & 6 & Chill & $\begin{array}{l}\text { R. } 48 \\
\text { T. } 104.8^{\circ} \\
\text { P. } \quad 88\end{array}$ & $\begin{array}{l}\text { R. U. } \\
\text { R. L. }\end{array}$ & Sterile \\
\hline 22 & $\approx 20$ & 5 & Chill & $\begin{array}{l}\text { F. } 24 \\
\text { T. } 105.6^{\circ} \\
\text { P. } 120\end{array}$ & I.. $\mathbf{L}$. & $\ldots \ldots \ldots$ \\
\hline 23 & $\begin{array}{l}\text { Â } 33 \\
\text { Alcoholic }\end{array}$ & 4 & ... & $\begin{array}{l}\text { R. } \quad 44 \\
\text { T. } 102.4^{\circ} \\
\text { P. } 100 \\
\text { R. } \quad 48\end{array}$ & R. L. & $\ldots \ldots \ldots$ \\
\hline
\end{tabular}




\begin{tabular}{|c|c|c|c|c|c|c|}
\hline \multicolumn{3}{|c|}{ Serum Administration } & \multicolumn{4}{|c|}{ Outcome of Disease } \\
\hline $\begin{array}{l}\text { Day of } \\
\text { Disease }\end{array}$ & $\begin{array}{l}\text { Dose, } \\
\text { Methods }\end{array}$ & Effect & $\begin{array}{l}\text { Termina- } \\
\text { tion of } \\
\text { Case }\end{array}$ & $\begin{array}{c}\text { Serum } \\
\text { Sicknes } \\
\text { and Day of } \\
\text { Disease it } \\
\text { Appeared }\end{array}$ & $\begin{array}{l}\text { Complica- } \\
\text { tions }\end{array}$ & Remarks \\
\hline 6 & $\begin{array}{l}200 \text { intrav. } \\
150 \text { intrav. }\end{array}$ & $\ldots \ldots \ldots$ & $\begin{array}{l}\text { Death. } \\
\text { Death. }\end{array}$ & $\cdots \ldots \ldots$ & $\ldots \ldots \ldots$ & $\begin{array}{l}\text { No effect of serum on } \\
\text { T., P. and R. Died } \\
\text { three days later. } \\
\text { Died in eighteen hours. }\end{array}$ \\
\hline 8 & 100 intrav. & $\cdots \cdots \cdots$ & $\begin{array}{l}\text { Crisis } 12 \text { th } \\
\text { d a y. R e- } \\
\text { covery. }\end{array}$ & $\begin{array}{l}\text { Ery thema } \\
\text { l4th day. }\end{array}$ & $\cdots \cdots \cdots$ & $\begin{array}{l}\text { No effect from serum. } \\
\text { Crisis fourth day } \\
\text { after serum. }\end{array}$ \\
\hline 6 & 150 intrav. & T. $2^{\circ}-$ & Death. & $\cdots$ & $\begin{array}{l}\mathrm{E} d \mathrm{e} m \text { a } \\
\text { lungs. }\end{array}$ & $\begin{array}{l}\text { Temperature rose stead- } \\
\text { ily; died eleventh } \\
\text { day. }\end{array}$ \\
\hline $\begin{array}{r}9 \\
11\end{array}$ & $\begin{array}{l}250 \text { intrav. } \\
50 \text { subc. }\end{array}$ & T. $41 / 2^{\circ}-$ & Death. & $\ldots \ldots \ldots$ & $\ldots \ldots \ldots$ & $\begin{array}{l}\text { Temperature fell after } \\
\text { fir s injection, but } \\
\text { rose again and rose } \\
\text { after second injection. }\end{array}$ \\
\hline $\begin{array}{l}4 \\
5\end{array}$ & $\begin{array}{l}250 \text { intrav. } \\
50 \text { subc. }\end{array}$ & 1. $3^{\circ}-$ & Death. & $\cdots \cdots \cdots$ & $\cdots \cdots \cdots$ & $\begin{array}{l}\text { Temperature drop ped } \\
\text { after first injection } \\
\text { and then rose. No } \\
\text { effect of serum. }\end{array}$ \\
\hline 12 & 50 subc. & T. $2^{\circ}-$ & $\begin{array}{l}\text { L y s i s. Re- } \\
\text { covery. }\end{array}$ & & & $\begin{array}{l}\text { Temperature fell } 2^{\circ} \text { and } \\
\text { then to normal after } \\
\text { serum. }\end{array}$ \\
\hline $\begin{array}{l}6 \\
9\end{array}$ & $\begin{aligned} 250 & \text { intrav. } \\
50 & \text { subc. }\end{aligned}$ & $\cdots \cdots \cdots$ & $\begin{array}{l}\text { Ly s i s. Re- } \\
\text { covery. }\end{array}$ & $\begin{array}{l}13 \mathrm{th} \text { d a } \mathrm{y} \\
\text { ras h and } \\
\text { fever; } 16 \mathrm{th} \\
\text { arthritis. }\end{array}$ & $\ldots \ldots \ldots$ & $\begin{array}{l}\text { Slow lysis interrupted } \\
\text { by serum sickness. }\end{array}$ \\
\hline $\begin{array}{l}4 \\
7\end{array}$ & $\begin{aligned} 250 & \text { intrav. } \\
50 & \text { subc. }\end{aligned}$ & & $\begin{array}{l}\text { Ly s i s. Re- } \\
\text { covery. }\end{array}$ & $\begin{array}{l}\text { A r thritis; } \\
\text { fever 18th } \\
\text { day. }\end{array}$ & $\begin{array}{l}\text { Pleurisy w i th } \\
\text { e ff u s o n : } \\
\text { tenth day, } 700 \\
\text { c.c. t u r b i d } \\
\text { s e rum; 12th, } \\
350 \text { c.c.; 25th. } \\
\text { pus. }\end{array}$ & $\begin{array}{l}\text { Serum without appar- } \\
\text { ent effect. }\end{array}$ \\
\hline 4 & 250 intrav. & $\begin{array}{l}\text { G e n e r a l } \\
\text { pains. }\end{array}$ & $\begin{array}{l}\text { Cris is } 5 \text { th } \\
\text { to } 6 \text { th day. } \\
\text { Recovery. }\end{array}$ & $\begin{array}{l}\text { Urt icaria } \\
\text { a f ter two } \\
\text { hours. }\end{array}$ & $\cdots \cdots \cdots$ & $\begin{array}{l}\text { Crisis twenty-four hours } \\
\text { after serum. }\end{array}$ \\
\hline 8 & 300 intrav. & $\cdots \cdots \cdots$ & $\begin{array}{l}\text { L y s i s. Re- } \\
\text { covery. }\end{array}$ & $\cdots \cdots \cdots$ & $\cdots \cdots \cdots$ & $\begin{array}{l}\text { Lysis rapid twenty-four } \\
\text { hours after serum. }\end{array}$ \\
\hline 6 & 250 intrav. & $\cdots \cdots \cdots$ & $\begin{array}{c}\text { Cris is } 6 \text { th } \\
\text { to 7th day. } \\
\text { Recovery. }\end{array}$ & $\ldots \ldots \ldots$ & $\ldots \ldots \ldots \ldots$ & $\begin{array}{l}\text { Crisis nine hours after } \\
\text { serum. }\end{array}$ \\
\hline 5 & 200 intrav. & $\begin{array}{l}\text { iv a u s a, } \\
\text { vomiting, } \\
\text { pulse rapid } \\
\text { and sweat- } \\
\text { ing. }\end{array}$ & $\begin{array}{l}\mathrm{Cr} \text { is is } 6 \text { th } \\
\text { d a y. R e- } \\
\text { covery. }\end{array}$ & $\cdots \cdots \cdots$ & $\cdots \cdots \cdots$ & $\begin{array}{l}\text { Crisis twent } y-\text { f o } u r \\
\text { hours after serum. }\end{array}$ \\
\hline
\end{tabular}


tolerated surprisingly well. In five patients, however, symptoms appeared that should be mentioned more in detail.

CASE 1.-A boy aged 12, received 50 e.c. of serum intravenously on the fourth day of his illness. A few minutes later the patient had a chill and his temperature rose from 104 to $107.2 \mathrm{~F}$. This was followed by a startling drop, and within six hours of the injection his temperature was $97.6 \mathrm{~F}$. The fever did not reappear, and convalescence was prompt and complete. I am inclined to regard this crisis as independent of the treatment, but at the time the sequence of events was very impressive.

CASE 8.-The patient was a negro, aged 30 , a rather heavy drinker and a driver of horses. When 80 c.c. of serum had run into the vein, he suddenly developed severe dyspnea, a very rapid and weak heart-action, profuse sweating and edema of the lungs. The serum was at once stopped. Within a few minutes the symptoms began to abate and within half an hour the lungs were nearly clear and his condition was satisfactory. The subsequent course of the pneumonia was typical and but moderately severe. Six days later, on the ninth day of the disease, defervescence by crisis occurred. Convalescence was interrupted only by symptoms of serum sickness.

CASE 20.-A boy aged 13, during the introduction of the serum complained of headache, pain in the abdomen and later in the legs. The pulse was acceler. ating and the serum was stopped, but not until he had received 200 c.c. Two hours later a profuse urticarial rash appeared on the abdomen and lasted a few hours. The patient had no late symptoms of serum-sickness.

CASE 23.-A man, aged 33, a heavy drinker, when 150 c.c. of serum had been given, became nauseated and vomited. These symptoms ceased in about five min. utes and 50 c.c. more of serum were given. At this time the pulse became rapid and the patient broke out in a profuse sweat. The serum was stopped and in a few minutes he was comfortable. He likewise had no late serum symptoms.

The effect of the serum on the leukocytes was determined by frequent blood-counts before and after the injections. No constant effects on the white cells could be made out. 'The results of some of these counts are detailed in Table 2 .

Late symptoms due to the serum were noticed in eight patients. In consideration of the large doses of unrefined horse-serum, this is not a surprisingly large number. The symptoms were not usually severe.

During the time of this experiment the First Medical Division of New York Hospital treated fifteen cases of pneumonia with six deaths, a mortality of 40 per cent., as compared with 30.5 per cent. for the serum cases. Of their ten cases with recovery, in six, or 60 per cent., there was defervescence by crisis. In the serum cases 50 per cent. of the patients who recovered had crisis. Only two of the control cases had complications, a percentage of 13.3. In the serum cases five patients, 22 per cent., had complicating inflammations. It does not seem that these were due to the use of the serum, but the number of patients with inflammations of the pleura (four cases, 17.4 per cent.) is uncomfortably large. 
TABLE 2.-BLOOD-Counts Berore AND AFter INJection

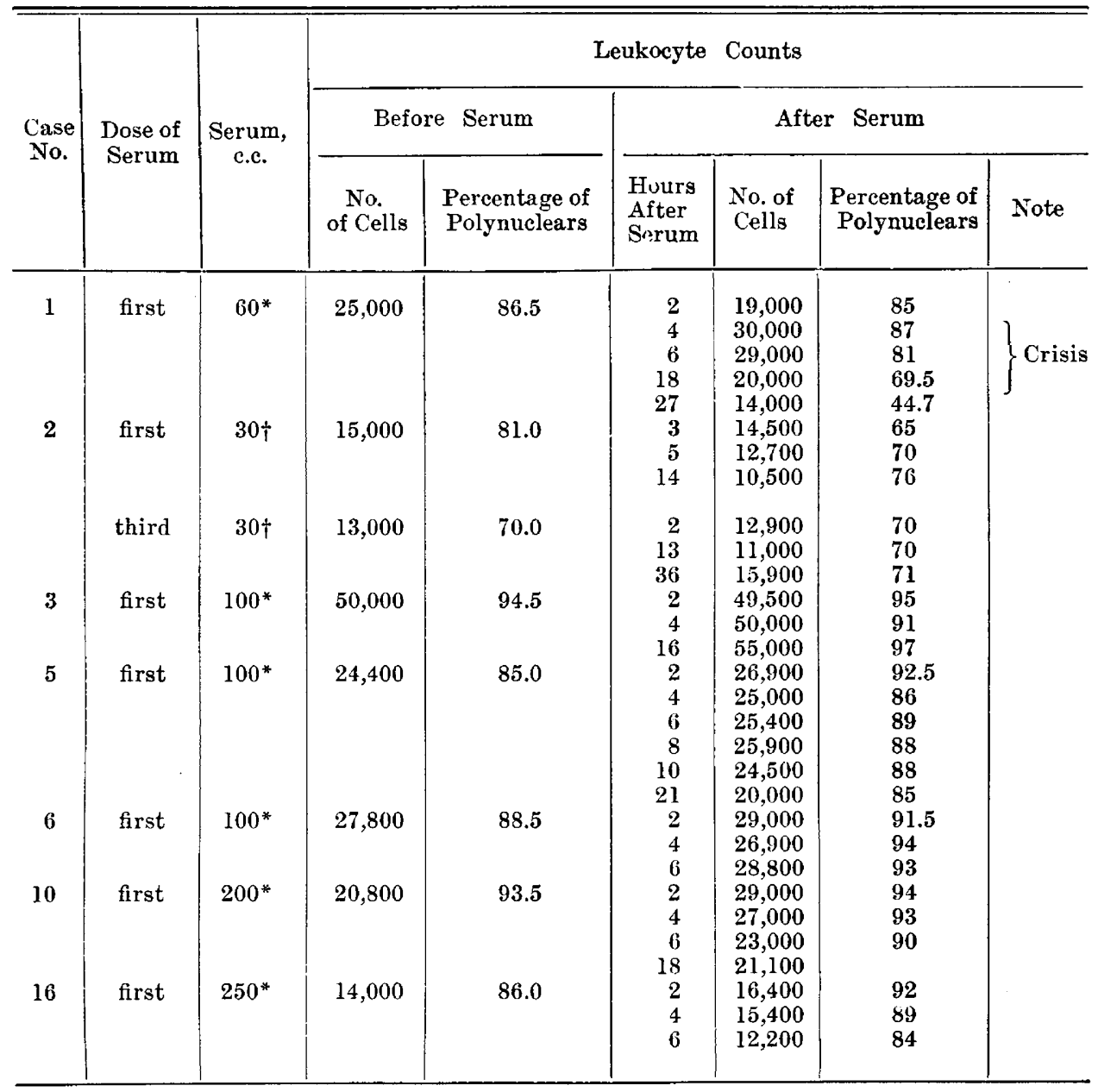

* Intravenous injection. $†$ Subcutaneous injection.

A study of the results of this treatment leaves one doubtful of the influence of the serum, in modifying favorably the course of the pneumonia.

The prosecution of this experimental study necessitated much extra work in the wards and laboratory. This was performed by the members of my house staff, Drs. Howard, Kutil, Alling and Wildman. I wish to thank them for their enthusiastic willingness, which made these observations possible.

NOTES ON SERUM, CULTURES, ETC.

CHARLES KRUMWIEDE, JR., M.D., NEW YORK

The serum was prepared by injecting a horse with pneumococci from varied sources. These cultures were all typical inulin fermenting types. They were 
isolated from the mouth in cases of Riggs' disease, from the sputum in cases of lobar pneumonia, from empyema, and from the meninges and blood of septic infections following the exanthems. The cultures used varied from time to time. As fresh cultures were isolated the older cultures were dropped. No attempt was made to raise the virulence of these cultures by passage through rabbits or mice. Although this may influence the protective value of the serum for these \&nimals, it is open to question what influence such adaptation to a new host has on the curative value in man. The cultivation on artificial medium undoubtedly changes the pneumococci, but how far this influences their ability to stimulate curative substances in the horse is unknown. The purpose was to prepare an immune serum against the prevailing strains of pneumococci, using the strains as little removed from human sources as possible; and to test the value of such serum for general use, where the immunological tests on each case would be impossible.

The injections at first were cultures in broth to which was added horse-blood. Later the cultures were grown on agar and washed off with water. At first the increasing doses were of cultures which had been heated to $55 \mathrm{C}$. for one hour. When the dose had reached the maximum decided on, live cultures alternating with autolysate were used. The autolysate was prepared by allowing distilledwater suspensions of the cocci to stand in the ice-chest for one week. The live cultures or the autolysate were added to the heated vaccine, in increasing amounts, until only the unheated culture or autolysate was given.

The injections were given once a week subcutaneously. The maximum dose equaled the growth on agar in 10-pint Blake bottles. The horse was receiving the total amount of live and autolyzed cocei at the time it was supplied to Dr. Williams. The bleedings were made every two weeks. Every effort was made to supply the fresh serum to avoid any possibility of deterioration. After the serum was drawn from the clot, several cubic centimeters of chloroform were added to each liter. In bottling the serum for use, the supernatant serum was drawn off and the lower portion containing sediment and excess of chloroform discarded.

The material from the cases was examined both for diagnosis, and in the hope that the cultures isolated could be studied for their complement-fixing power, with the serum used, and that the protection value of the serum could be tested on the type of pneumococci found. This study was not made, partly because of other work, and partly because the strains were found to possess such low virulence for rabbits. When the intravenous inoculation of the growth from one bıood agar slant was given, only two strains killed, one in forty-eight hours, the other after ten days. Cultures isolated from the heart's blood of these rabbits did not kill other rabbits when a somewhat smaller dose was used. The sputum from Cases 18 to 23, inclusive, was examined. They all showed an overwhelming preponderance of typical pneumococci. One case of the series showed the presence of an abundance of Streptococcus mucosus. 